\title{
PRESERVING THE WHOLE THEOLOGICAL SYSTEM: MAXIMUS THE CONFESSOR'S DYOTHELITISM AS A BULWARK FOR TRINITARIAN THEOLOGY, CHRISTOLOGY, AND SOTERIOLOGY
}

In Maximus's Liber asceticus, a young brother opens the discourse by asking a wise old man (o $\gamma \varepsilon \dot{\varepsilon} \rho v$ ) about the reason for the Incarnation. The old man is amazed at his question because they do, after all, hear the answer proclaimed daily in the Creed; nonetheless, he answers quite plainly that it was for the sake of human salvation ${ }^{1}$. This work is likely among the earliest writings ${ }^{2}$ from the hand of Maximus the Confessor, and it reveals a theme that would carry through his monastic works into his Christological treatises near the end of his life. As ecclesial and political events of the seventh century would draw his attention, he would consistently give a response similar to that of the $\gamma \dot{\varepsilon} \rho \omega v$, that all things having to do with Christology would be interpreted in a soteriological framework and in a manner harmonious with Trintiarian theology. As a clearer picture of Christology had developed by the seventh century, the form of the discussion about the incarnational union shifted its focus onto the interrelated topics of will $(\theta \dot{\varepsilon} \lambda \eta \mu \alpha)$ and operation $\left(\varepsilon \dot{\varepsilon} \varepsilon^{\rho} \rho \varepsilon \imath \alpha\right)^{3}$ in Christ. Around these topics arose two heresies: monothelitism, which teaches that there is only one will in Christ, and monenergism (often monoenergism), which teaches that there is only one operation in Christ ${ }^{4}$. The

${ }^{*}$ Kevin M. Clarke - Adjunct Professor of Biblical Languages in John Paul the Great Catholic University in San Diego, California, USA; PhD Candidate in Theology at Ave Maria University, Ave Maria, Florida, USA; e-mail: kevinmclarke@gmail.com.

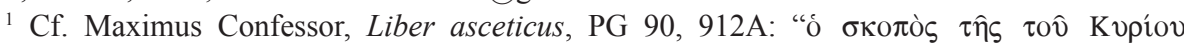

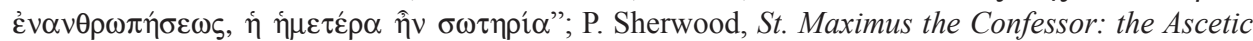
Life, the Four Centuries on Charity, Ancient Christian Writers 21, New York 1955, 103.

${ }^{2}$ Regardless of whether one follows the hagiographic life of Maximus or the Syriac one, the Liber asceticus is dated to the earliest period of Maximus's oeuvre. Cf. M. Jankowiak - Ph. Booth, A New Date List of the Works of Maximus the Confessor, in: The Oxford Handbook of Maximus the Confessor, ed. P. Allen - B. Neil, Oxford 2015, 19-83; P. Sherwood, Annotated Date-list of Maximus' Works, Studia Anselmiana 30, Roma 1952, 23-64.

${ }^{3}$ In general, I have tended to prefer the term "operation" to "energy" as a translation of $\dot{\varepsilon} v \varepsilon \dot{\varepsilon} \rho \gamma \varepsilon 1 \alpha$ since it more reflects the active agency that the Greek term is meant to convey. Other translators of Maximus and authors in the secondary literature also use the words "activity" or "work".

${ }^{4}$ This is a bit of a simplification, as these heresies were not known to be pedagogically con- 
orthodox response could adequately be characterized by the terms dyenergism and dyothelitism. In this paper, I will examine the theological stakes on the table for orthodoxy that prompted Maximus's entry into the debate, focusing first on the mode of union of the Incarnation and the consequences for human divinization. Then, I will consider Maximus's presentation of the synthetic heterodoxy: that a composite will ultimately destroys all theology. I will then offer some observations about the immediate reception of Maximus's teachings. Finally, I will reflect upon his continued relevance, especially in light of contemporary challenges which call for the Maximian voice.

Some context of the soteriological framework of Maximus's Christology is helpful. From the time of Christ's sojourn in the flesh, his followers have wondered at the twoness of the one Christ. "Who then is this, that he commands even wind and water, and they obey him?" (Lk 8:25) continued into the Patristic age, as the Church sought to articulate who Christ was in relation to the one God, who is three hypostases and one divine nature. Not long after the death of the great Cyril of Alexandria, the Council of Chalcedon convened in 451 to describe the manner of the union of the two natures in the one person of Christ, namely that they were united without confusion, change, division, or separation ${ }^{6}$. After the Second Council of Constantinople in 553, which cleared up the post-Chalcedonian confusion by describing the personal mode of the union of natures, a new controversy arose concerning the will and the activity of Christ. By the reasoning of Maximus's opponents, since there is one person of the Word, there would seem to be only one will in him. Further, since there was only one Christ (and since the Nestorian position had been defeated), it would likewise seem that there must be only one operation in him $^{7}$. Humans have wills that seem as numerous as there are willing individuals. It seems, therefore, the will must be in the person, not in the nature. Additionally, to posit two wills in Christ would seem necessarily to bring about a sort of opposition within him. These were the thoughts of some, such

sistent. As François-Marie Léthel has pointed out, it is difficult to narrow down the heterodoxical movements of the seventh century to a single form of monothelitism or monenergism. Political interference conditioned the shifting theology. In fact, Léthel distinguishes between what he calls the "Byzantine monothelitism" that seems to be more theologically integral and a "common monothelitism or propaganda" that seems to be devoid of coherence. Cf. F.-M. Léthel, Théologie de l'Agonie du Christ: La liberté humaine du Fils de Dieu et son importance sotériologique mises en lumière par Saint Maxime Confesseur, Théologie Historique 52, Paris 1979, 26-28.

${ }^{5}$ Cf. Mt 16:16-19; Lk 7:49; Jn 20:28; Phil 2:5-11.

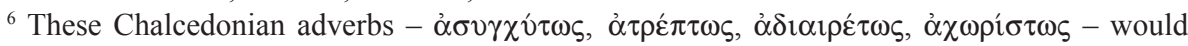
become a distinguishing mark in the writings of the Greek fathers thenceforth.

${ }^{7}$ For a brief overview of the secular and ecclesial developments that produced the monenergist and monothelite controversies, see Sherwood, St. Maximus the Confessor, p. 10-28, and J.-C. Larchet, Introduction, in: Sainte Maxime Le Confesseur, Opuscules Théologiques et Polémiques, introd. par J.-C. Larchet, trad. et notes par E. Ponsoye, Sagesses chrétiennes, Paris 1998, 10-14. 
as Sergius and Pyrrhus, successive patriarchs of Constantinople ${ }^{8}$. For the holy monk Maximus, who would pay the price of orthodoxy in his flesh, the solution was simple, anchored in the mystery of the Trinity, founded in Scripture and further backed with the authority of Gregory the theologian, Dionysius the Areopagite, and Cyril of Alexandria9: will and operation are in the nature; locating them in the person not only annihilates the Incarnation but also divides God's oneness. That is the main point I wish to argue. Maximus is not dealing with bare metaphysical distinctions; rather, the ramifications for man's salvation and deification are interwoven into these controversies. It is a consequential project for Maximus, who along the way manages to reclaim some seemingly problematic sayings of the earlier fathers. Maximus's tactic is to show that monothelitism and monenergism both necessarily annihilate Trinitarian theology, Christology, and consequentially soteriology. The idea of a personal will would bring about an intolerable opposition within the Trinity, estranging Christ from God because of the absurdity of a composite will and estranging Christ from man for the same reason. Against Pyrrhus, Maximus effectively constructs a sort of reductio ad Nestorium, or perhaps even a reductio ad omnes haereses. Maximus extends the soteriological assumption theory of Gregory Nazianzen ${ }^{10}$ to show that if Christ had not assumed a human will and a human operation, the disorder in man's natural will and operation would not have been healed ${ }^{11}$, nor would mankind ever come to full divinization.

\section{Passions, appropriation, and $\gamma \nu \omega ́ \mu \eta$ in Christ relative to soteriology.} Some key intersections between monastic ascetic struggle and Christology are worth noting. On the one hand, Maximus is eager to extinguish the smoldering Origenism in monastic life, such as the belief that souls had natural foreknowledge with Christ in a primordial state before embodiment ${ }^{12}$. On the other hand,

${ }^{8}$ Cf. H. Urs von Balthasar, Cosmic Liturgy: The Universe According to Maximus the Confessor, transl. B.E. Daley, San Francisco 2003, 75-77.

${ }^{9}$ Maximus makes his disposition towards the Fathers clear to Pyrrhus, saying that it cannot be granted to affirm that the Fathers of the Church ever taught one will. Rather, he puts Sergius and his Ekthesis in continuity with the one he identifies as monothelitism's true father, Nestorius (cf. Maximus Confessor, Disputatio cum Pyrrho, PG 91, 313B - 316C).

${ }^{10}$ Gregory Nazianzen and Dionysius the Areopagite have an exalted place in the works of Maximus; his Ambigua are devoted to interpreting difficult passages written by these saints. It seems he even views these works as inspired, saying that it was not these men, but Christ who wrote the passages, "who by grace has exchanged places with them". Cf. Maximus Confessor, Ambiguorum liber, Prologus, PG 91, 1033A, transl. N. Constas: Maximus Confessor, On Difficulties in the Church Fathers: The Ambigua, vol. 1, Dumbarton Oaks Medieval Library 28, Cambridge (Ma) 2014. Translations of Maximus's Ambigua used in this paper are from Constas, and the Greek is included where appropriate.

${ }^{11}$ Cf. Gregory Nazianzen's first letter to Cledonius, Epistula 101, which is translated in the Popular Patristics Series volume On God and Christ, transl. L. Wickham, Crestwood (NY) 2002, 158: "The unassumed is the unhealed, but what is united with God is also being saved".

${ }^{12}$ Cf. Maximus Confessor, Quaestiones ad Thalassium 60, PG 90, 625A-B. 
he preserves much of the Evagrian tradition with regard to ascetic struggle and the understanding of the usefulness $(\chi \rho \hat{\eta} \sigma ı \varsigma)$ of the passions. Paul Blowers frames the question of the healing of the passions in a Christological context saying that there is a "mysterious and salvific tension within Christ's hypostasis between his embodiment of a new and eschatological mode ( $\tau \rho{ }_{0} \pi \mathrm{o} \varsigma$ ) of

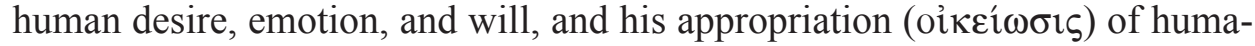
nity's fallen and passible nature"13.

Assumption of the passions has a soteriological purpose for Maximus in his exegesis of Colossians 2:15 in Ad Thalassium 21, which describes how the evil powers tempted Christ in the desert by passions associated with pleasure

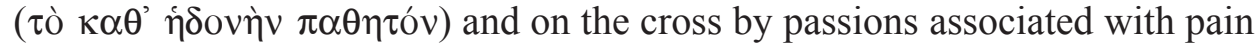

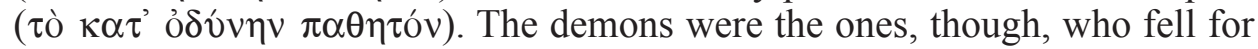
the trap of the victorious Christ:

"Since he assumed our nature's liability to passions, albeit without $\sin$ (cf. Heb 4:10), thereby inciting every evil power and destructive force to go into action, he despoiled them at the moment of his death, right when they came after him to search him out. He triumphed ( $\mathrm{Col} 2: 15)$ over them and made a spectacle of them in his cross, at the departure of his soul, when the evil powers could find nothing at all [culpable] in the passibility proper to his human nature. For they certainly expected to find something utterly human in him, in view of his natural carnal liability to passions. It seems that in his proper power and, as it were, by a certain «first fruits» of his holy and humanly begotten flesh, he completely freed our human nature from the evil which had insinuated itself therein through the liability to passions. For he subjugated - to this very same natural passibility - the evil tyranny which had once ruled within it (within that passibility, I mean)"14.

In this excerpt, one sees an approach to the passion and death of Christ similar to that of the "fishhook". Christ baits the demons by the passions of his own human nature and then conquers the demons when they peer into him, looking for evidence of their success and finding none.

But Christ's appropriation of our nature does not extend, for Maximus, into the realm of $\gamma v \omega ́ \mu \eta$, which (despite the great range of this term) means the vacillation between good and evil. In the heat of the monothelite controversy, Maximus wrote that were Christ to have possessed a gnomic will, he would have been

"double-minded and double-willed, and fighting against himself, so to speak, in the discord of his thoughts, and therefore double-personed. For [the Fathers] knew that it was only this difference of gnomic wills that introduced into our

${ }^{13}$ P. Blowers, The Dialectics and Therapeutics of Desire in Maximus the Confessor, VigCh 65 (2011) 431.

${ }^{14}$ Maximus Confessor, Quaestiones ad Thalassium 21, PG 90, 315A-C, transl. P.M. Blowers - R.L. Wilken, in: On the Cosmic Mystery of Jesus Christ: Selected Writings from St. Maximus the Confessor, Popular Patristics Series, Crestwood (NY) 2003, 113. 
lives sin and our separation from God. For evil consists in nothing else than this difference of our gnomic will from the divine will"'15.

This is a position on which Maximus seems to have evolved throughout his theological career. His earlier works asserted that Christ assumed $\gamma \nu \omega \mu \mu \eta$ in order to perfect it and be the model of the human ascent through a succession of free choices. Blowers explains the reason for the change, saying

"that $\gamma \nu \omega ́ \mu \eta$ is a particularized «mode» of willing, grounded in an individual human hypostasis. In Christ, however, there is no such hypostasis; there is only his composite hypostasis, the hypostasis of the divine Son perfectly united to Jesus' humanity, within which «particularized» human choices and acts come about solely through his natural human will ( $\theta \dot{\varepsilon} \lambda \eta \mu \alpha$ $\varphi v \sigma \imath \kappa \eta ́)$, which is completely deified"16.

Since there is no $\gamma \nu \omega ́ \mu \eta$ in Christ, is this then "unhealed"? ${ }^{17}$ Hans Urs von

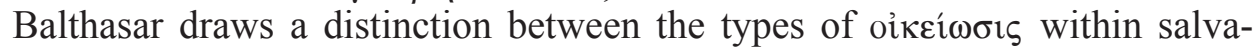
tion history:

"This can take two forms: an «appropriation by relationship» (oikeí $\omega \sigma ı \varsigma$

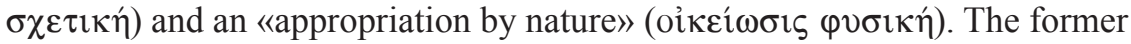
comes into being by conscious acts; so, for example, if we love each other, we can communicate our actions and our sufferings and can identify with those of another, although we are not ourselves actually doing or undergoing

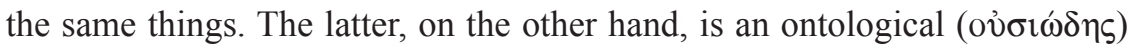
appropriation, which makes the assimilated object part of our very being. Now it is clear that Christ, who possessed our nature ontologically as his own, had our natural human capacity to will in himself in the same way that

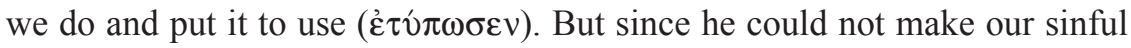
manner of willing his own ontologically, he assimilated it to himself through «relative appropriation»"18.

${ }^{15}$ Maximus Confessor, Opuscula theologica et polemica 3, PG 91, 55B, transl. A. Louth, in: idem, Maximus the Confessor, London 1996, 197.

${ }^{16}$ P. Blowers, Maximus the Confessor and John of Damascus on Gnomic Will ( $\left.\gamma \nu \omega \dot{\mu} \eta\right)$ in Christ: Clarity and Ambiguity, "Union Seminary Quarterly Review" 63 (2012) 44-50. Cf. J-M. Garrigues, L'Instrumentalité Rédemptrice du Libre Arbitre du Christ chez Maxime le Confesseur, "Revue Thomiste" 104 (2004) fasc. 4, 531-550; I.A. McFarland, "Willing Is Not Choosing”: Some Anthropological Implications of Dyothelite Christology, "International Journal of Systematic Theology" 9 (2007) fasc. 1, 3-23; idem, The Theology of the Will, in: The Oxford Handbook of Maximus the Confessor, p. 516-532. Blowers finds difficulty with this change in Maximus's thought on $\gamma \nu \omega \mu \eta \eta$, a usage that he points out would be echoed by John Damascene, though not without lea-

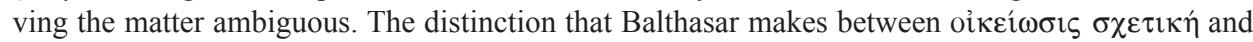

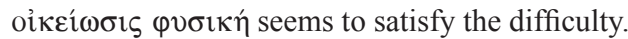

${ }^{17}$ Cf. Gregorius Nazianzenus, Epistula 101.

${ }^{18}$ Balthasar, Cosmic Liturgy, p. 266-267. Cf. Maximus Confessor, Disputatio cum Pyrrho, PG 91, 304A - 309B. 
Since $\gamma \nu \omega ́ \mu \eta$, therefore, is a result of original sin, it is not in Christ naturally, that is, ontologically. Indeed, it ought not be. Why should the natural will of Christ need to deliberate between good and evil? I think that many believers would prefer that to be the case-somehow that might make Jesus more like us. That is no doubt true, but only in a certain manner: that of sinful inclinations. The key question is whether not assuming sinful inclinations deprives Christ of the full human nature. If Maximus did indeed evolve on this, he evolved in the right direction. There is no inner necessity in Christ's healing human nature by means of assuming a human will that vacillates hither and thither between good and evil. It also is the solution most in accord with the Biblical narrative, in which Christ speaks often of his having come for the very purpose of death and resurrection ${ }^{19}$. Nowhere in the gospels does he shrink from his purpose; thus, it seems somewhat unfitting to suggest his agony was a matter of whether or not to go through with his passion. Perhaps some may find that

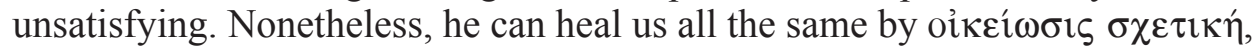
a sort of appropriation-by-compassion. This has obvious consequences for our understanding the dyothelite doctrine intelligibly ${ }^{20}$.

2. Addressing the composite heterodoxy. At this point, let us focus a little more closely on the disputes. Throughout, Maximus worked not only to show continuity with Scripture but also with the fathers. Maximus's resistance to monothelitism and monenergism is grounded in original and penetrating theological reflection, but he would not venture so boldly were he not certain that he spoke from within the currents of proper scriptural exegesis and patristic

\footnotetext{
${ }^{19}$ Cf. Mt 16:21; 26:2; Lk 24:6-7; Jn 12:23-27; 13:1; 16:28.

${ }^{20}$ Thomas Aquinas's account is worth a look. Thomas was not very familiar with Maximus's work. He comes to him in a round-about way through John of Damascus. Benjamin Heidgerken has pointed out that John of Damascus was in some ways a "compiler" who mediated the thought of Maximus to Thomas. Regarding an anthropological point of divergence between Maximus and John worth noting here, Heidgerken points out that John's understanding of $\beta$ ov́ $\lambda \eta \sigma ı \varsigma$ was slightly different from that of Maximus, in that for John ßov́ $\lambda \sigma i \varsigma$ could include an evil wish, whereas for Maximus it could not. Cf. B. Heidgerken, The Christ and the Tempter: Christ's Temptation by the Devil in the Thought of St. Maximus the Confessor and St. Thomas Aquinas, Dayton 2015 (Ph.D. diss.); Joannes Damascenus, De fide orthodoxa 2, 22. Thomas points out in an objection how John denies $\gamma \nu \omega ́ \mu \eta$ and $\pi \rho o \alpha i p \varepsilon \sigma ı \varsigma$ (free choice) to Christ; thus, there is no free will in Christ. But in the response, Thomas says this: "Damascene excludes choice from Christ, in so far as he considers that doubt is implied in the word choice. Nevertheless doubt is not necessary to choice, since it belongs even to God Himself to choose, according to Eph 1:4: He chose us in Him before the foundation of the world; although in God there is no doubt. Yet doubt happens to choice when it is in an ignorant nature. We may also say the same of whatever else is mentioned in the passage quoted" (Summa Theologiae III q. 18 a. 4 ad 1). Secondly, Aquinas resolutely solves the difficulty of the full healing of our will in his understanding of the agony in the garden. The resistance in the garden was not the vacillation characteristic of $\gamma \nu \omega \dot{\omega} \mu$; rather, it was Christ's repulsion to the means while willing the end both as God and as man. That is the answer to the difficulty, which is still harmonious with Gregory Nazianzen's assumption doctrine.
} 
tradition $^{21}$. In the Disputation with Pyrrhus, both displaced interlocutors attempted to establish a link with Dionysius the Areopagite for their own positions. As Nicholas Constas points out, the so-called "pact of union" that reconciled the monophysites with the Church adopted an altered version of the Dionysian quote, substituting the word "one ( $\mu$ í $\alpha v)$ theandric energy" for

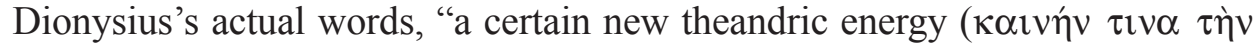

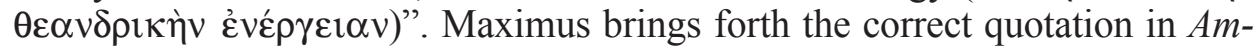
biguum 5 and unpacks his dyenergist apologia ${ }^{22}$. For Maximus to lay hold of Dionysius as a witness, he has to rescue him from the grasp of the monenergists

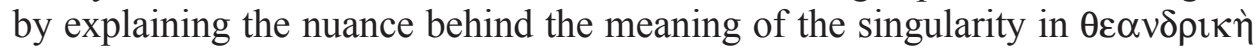

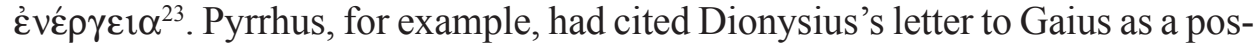
sible support for monenergism. Maximus asks whether this newness is a quality or a quantity. In response to Pyrrhus, who had asserted that the union of Christ was a new quantity rather than a new quality, Maximus corrects him saying,

${ }^{21}$ Some recent studies have suggested that dyothelitism is the "younger brother" of monothelitism. Cf. M. Jankowiak, The Invention of Dyotheletism, StPatr 63 (2013) 335-342. It seems that Jankowiak is trying to recover monothelitism as orthodoxy itself (cf. ibidem, p. 335). Yet to suggest that monothelitism antedates dyothelitism, while fascinating and novel, is unhistorical and assumes a strikingly narrow view of dyothelitism. Indeed, the shape of the discussion over the two wills of Christ was in many ways conditioned by the advent of monothelitism, but in no way did it generate or even precede dyothelitism. There have been numerous studies on the dyothelitism of Augustine of Hippo, for example, whose theological descendants a quarter of a millennium later would have been in contact with Maximus during his stay in Carthage and during his time in Rome. This seems to be substantiated by the documents of the Lateran Council in 649. While it remains inconclusive whether Maximus himself used Augustine directly, clearly one can speak of a theological reflection on the human will of Christ in relation to the divine will (i.e., a "dyothelitism") before Maximus. Cf. G.C. Berthold, Did Maximus the Confessor Know Augustine?, StPatr 17 (1982) fasc. 1, 14-17; B.E. Daley, Word, Soul, and Flesh: Origen and Augustine on the Person of Christ, AugSt 36 (2005) fasc. 2, 299-326; idem, Making a Human Will Divine: Augustine and Maximus on Christ and Human Salvation, in: Orthodox Readings of Augustine, ed. G.E. Demacopoulos - A. Papanikolaou, Crestwood (NY) 2008, 101-126; J. Börjesson, Maximus the Confessor's Knowledge of Augustine: An Exploration of Evidence Derived from the Acta of the Lateran Council of 649, StPatr 68 (2013) 325-336; idem, Augustine on the Will, in: The Oxford Handbook of Maximus the Confessor, p. 212-234; G.C. Berthold, Dyothelite Language in Augustine's Christology, StPatr 70 (2013) 357-364; H. Kantzer Komline, The Second Adam in Gethsemane: Augustine on the Human Will of Christ, REAug 58 (2012) fasc. 1, 41-56; idem, "Ut in illo viveremus": Augustine on the Two Wills of Christ, StPatr 70 (2013) 347-355.

${ }^{22}$ Cf. Maximus Confessor, Ambiguorum liber 5, PG 91, 1056B, transl. Constas, vol. 1, p. 48. See especially Constas's notes 16 and 17 on this difficult text, p. $476 .$.

${ }^{23}$ Maximus has a helpful forerunner in his spiritual mentor, the monk Sophronius. Daley observes that Sophronius reads this quote of Dionysius similarly, that is, not ontologically, but as a "linguistic move designed to show the mutual inflection - the «synergy» - of Christ's human and divine performance in the world". Cf. B.E. Daley, Maximus Confessor, Leontius of Byzantium, and the Late Aristotelian Metaphysics of the Person, in: Knowing the Purpose of Creation through the Resurrection: Proceedings of the Symposium on St. Maximus the Confessor, Oct. 18-21, 2012, Belgrade, ed. Bishop M. Vasiljević, Belgrade 2013, 60-61. 
"Well then, it also introduces with itself a new nature such as this, since the definition of every nature stands as the principle of its essential energy. Not only this, but also when the Apostle should say, «Behold, all things have become new», he would be saying nothing other than that «Behold, all things have become one». But whether you wish to call this newness in nature or in energy, this newness would be of our power. But if the newness is a quality, it makes plain not one energy, but the new and ineffable manner of the manifestation of the natural energies of Christ, suitably by the ineffable manner of interpenetration ( $\pi \varepsilon \rho \iota \chi \omega \rho \eta \sigma \varepsilon \omega \varsigma)$ of the natures of Christ into one another, and his humanly way of life, an existence strange and incredible, and unheard of in the nature of existing beings, and the manner of exchange according to the ineffable union"24.

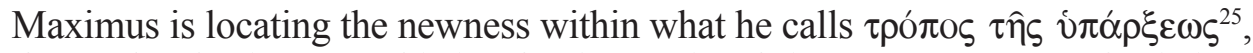
the mode of existence. This is what is new in Christ: a new manner of existing. Because of this new mode, He accomplishes the economy of salvation, to borrow from the Areopagite's language, "theandrically" $(\theta \varepsilon \alpha \nu \delta \rho \imath \kappa \hat{\omega} \varsigma)$. "To put it more clearly, His «life among us» was such that divine and human energy coincided in

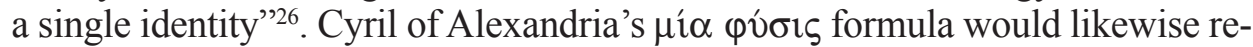

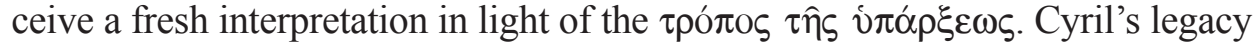
was on the line in the monothelitism-monenergism crisis, but Severus's interpre-

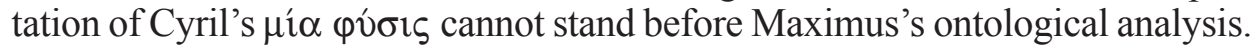
Maximus points out that if Severus were right, Christ's one nature would be either generic or singular; thus, there could either be many Christs in the former case or there would be no consubstantiality with God or man in the latter ${ }^{27}$.

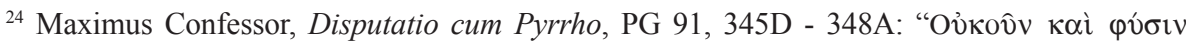

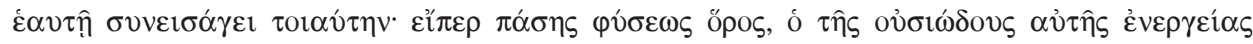

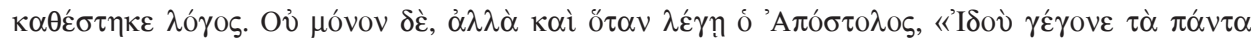

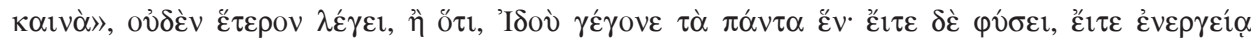

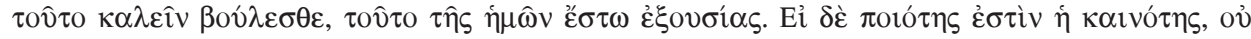

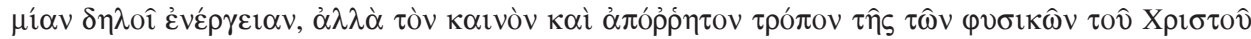

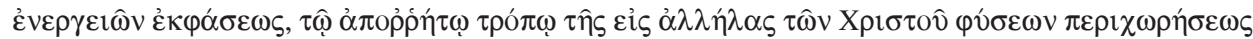

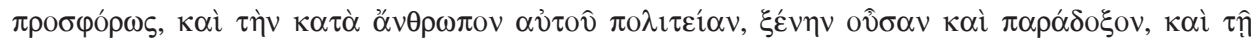

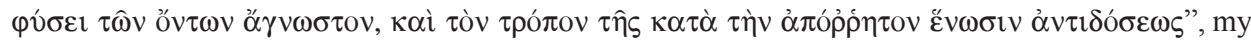
own translation. Cf. idem, Ambiguorum liber 5 (PG 91, 1056D), where Maximus describes Dionysius's expression as a "circumlocution" ( $\pi \varepsilon \rho i \varphi \rho \alpha \sigma \imath \varsigma)$ meant to describe the union.

${ }^{25}$ Cf. A. Lévy, Le Créé et L'Incréé: Maxime le Confesseur et Thomas D'Aquin: Aux Sources de la Querelle Palamienne, Paris 2006, 325-334.

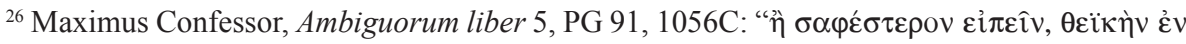

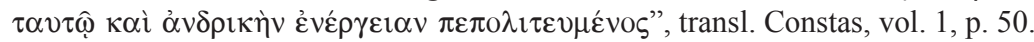

${ }^{27}$ Cf. N. Madden, Composite Hypostasis in Maximus Confessor, StPatr 27 (1993) 181. According to Lars Thunberg, Maximus maintained, particularly in his twelfth letter, that "Cyril never intended to abolish the difference between the natures of Christ after their union ( $\varepsilon v \omega \sigma i \varsigma)$, as Apollinaris, Eutyches and Severus wished to do, a fact which Cyril himself had also quite clearly pointed out". Not only does Maximus defend Cyril's formulation, but he avers that it is a fitting description of the manner of the union of the two natures (cf. L. Thunberg, Microcosm and Mediator: The Theological Anthropology of Maximus the Confessor, Lund 1965, 41-43). 
Maximus uses the term $\pi \varepsilon \rho \imath \chi \omega \rho \eta \operatorname{\sigma s}$ to show the mutual interpenetration of the two natures of Christ. This term is used in a manner in order to achieve the greatest possible union while preserving the distinction between the nature ${ }^{28}$. Maximus likely appropriated the term from St. Gregory Nazianzen ${ }^{29}$, establishing it as a technical term for post-Chalcedonian theology. As Lars Thunberg

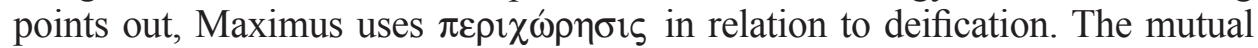
interpenetration of divine and human in Christ is seen in a Chalcedonian light, which at once preserves the distinction and achieves the perfection of union, for a perfect union would not obliterate the distinction between two things. The analogous image is that of the heated sword, retaining all the properties of both iron and fire. Moreover, the heated sword "glows in a way proper to iron alone". One could also say it cuts in a way proper to heat. Likewise, man is divinized in Christ in an altogether human manner. To take it a bit further, as Thunberg says, this is "in full accordance with human nature as such" ${ }^{30}$. The first cause and the final cause are one in the same; the mediator is Jesus Christ.

Maximus's Christology of the two operations flows naturally into the doctrine of man's $\theta \varepsilon \hat{\omega} \sigma \mathrm{s}$. Maximus sees the full implication of the exitus-redditus

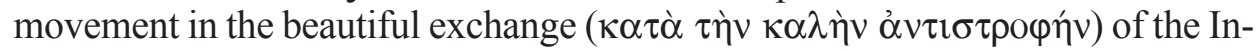

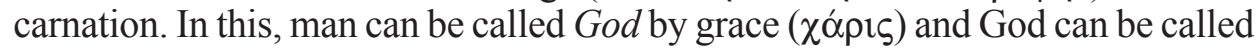
man by His condescension ( $\sigma v \gamma \kappa \alpha \tau \alpha \beta \alpha$ ó $\left.\iota_{\varsigma}\right)$. The reciprocity of the union is

"a power that divinizes man through his love for God, and humanizes God through his love for man. And by this beautiful exchange, it renders man God by reason of the divinization of man, and God man by reason of the Incarnation of God"31.

${ }^{28}$ Later, John of Damascus will employ this word for describing Trinitarian relations. Cf. Joannes Damascenus, De fide orthodoxa 3, 5, PG 94, 1000B.

${ }^{29}$ Cf. Gregorius Nazianzenus, Epistula 101, PG 37, 181C.

${ }^{30}$ Thunberg, Microcosm and Mediator, p. 27-36. Maximus unpacks this analogy in Opuscula theologica et polemica 16, PG 91, 189C - 192A.

${ }^{31}$ Maximus Confessor, Ambiguorum liber 7, PG 91, 1084C. How Maximus sets up the parallel reciprocity in this passage is more evident when observing the Greek:

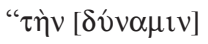

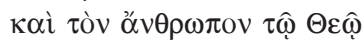

$\theta \varepsilon \circ \hat{\sigma} \sigma \alpha \nu$

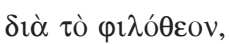

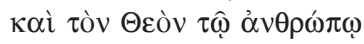

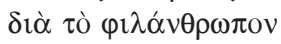

$\dot{\alpha} v \theta \rho \omega \pi i \zeta o v \sigma \alpha \nu$

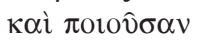

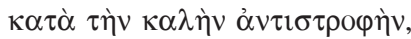

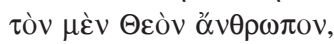

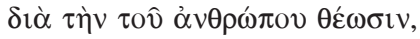

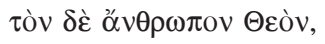

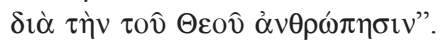




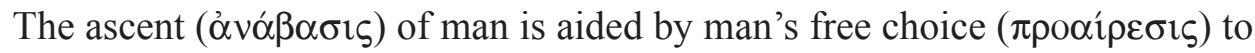
grow in God's likeness through the exercise of the virtues ${ }^{32}$.

There is an interesting tension between orthodoxy and the two heresies Maximus battled. Just as the answer to the difficulties lay in Christ's composite hypostasis, so the difficulty itself sprang from a single confusion concerning the manner of Christ's union. With regard to the question of whether there were one or two wills in Christ, the answer for Maximus was to be found in Gethsemane. Christ's prayer to the Father, what was it? In light of Christ's vi ó $\sigma \tau \alpha \sigma \iota \varsigma$, could it even be a real prayer? "My Father, if it is possible, let this cup pass from me; nevertheless, not as I will, but as you" (Mt 26:39). Maximus turns to Gregory Nazianzen who pointed out that "his will in no way contradicts God, since it has been completely deified" ${ }^{\prime 3}$. What's more is that even should there be some appearance of opposition between the wills, instead there is harmony. Pyrrhus brings up this contention in the debate with Maximus - two wills in one person would necessarily create opposition $(\dot{\varepsilon} v \alpha \nu \tau i \omega \sigma ı)^{34}$. Bishop Theodosius does too in his dispute with Maximus at Bizya. He states that

"we too confess both the natures and different activities, that is to say, both the divine and the human, and we confess that his divinity has a will, and his humanity has a will, because his soul was not without a will. But we do not speak of two, lest we introduce him as being at war with himself ( $\Delta$ v́o $\delta \dot{\varepsilon}$ o

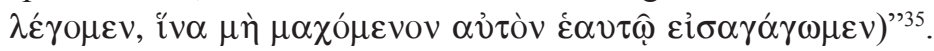

Theodosius's theological reasoning is a little perplexing, as this is near the end of the confessor's life and Theodosius is attempting to coerce Maximus back into communion with Constantinople. Regardless, this theory of opposition is an all too postlapsarian way of considering the interplay of personal wills, one that seems to fail to consider even the possibility of harmony. Indeed, this seems to be one of monothelitism's greatest shortcomings. Anyone who would try to advance a monothelite position ought to contend with all three synoptic Gethsemane accounts, which are similar and which clearly indicate some sort of difference between the will of Christ and the will of the Father ${ }^{36}$.

${ }^{32}$ Cf. ibidem, PG 91, 1084A-C.

${ }^{33}$ Cf. Gregorius Nazianzenus, Oratio 30, 12. This is cited in: Maximus Confessor, Opuscula theologica et polemica 6, PG 91, 65B, transl. Blowers - Wilken, in: On the Cosmic Mystery of Jesus Christ, p. 173.

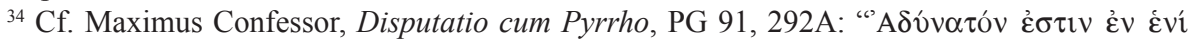

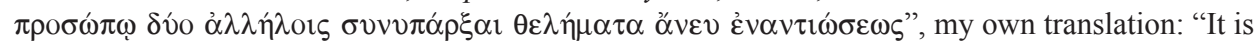
impossible in one person for two wills to coexist with one another without opposition".

${ }^{35}$ Disputatio Bizyae cum Theodosio 4, ed. and transl. P. Allen - B. Neil: Dispute at Bizya with Theodosius, in: Maximus the Confessor and his Companions: Documents from Exile, Oxford 2004, 97.

${ }^{36}$ Thus, one sees, for example, in the letter of Pope Honorius to the Patriarch Sergius wherein Honorius when he attempts to account for Gethsemane goes so far as to deny that there was a different or opposing will in the Savior. Regarding this, Léthel observes that difference does not necessarily mean opposition, saying, "On remarque dans ce texte la confusion entre volonté différente et 
If they could explain away this Scripture, the monothelites would seem to have a point ${ }^{37}$. At least on the surface, willing seems to be better assigned to person than to nature. Thus, they unsurprisingly arrive at hypostatic will.

There are, however, numerous problems - Christological and Trinitarian to assigning willing to the person rather than to the nature. First of all, Christ is a divine person, and so if he were to have only one will (a divine one), it would be absurd that there should be any speaking of difference in wills between the Son and the Father in Gethsemane. Maximus explains how such a position has dire soteriological consequences: refusal of the chalice "would be a negation of what is willed by God, namely, our salvation". The second point is no less soteriological: If there were to be no human will in Christ, there would be something not fully assumed in the Incarnation. Thus, human willing would not be redeemed. Instead, Jesus' phrase "not what I will" reflects the deep "harmony between the human will of the savior and the divine will shared by him and the Father, given that the Logos assumed our nature in its entirety and deified his human will in the assumption" 38 . Maximus speaks similarly with Pyrrhus. From the beginning of the debate, Maximus ties the question to salvation:

"For as the number of his natures - he is also one Christ, to think and speak piously - did not divide the Christ, not only that but also the difference of the natures being preserved should stand beside each other in oneness, so, also, the number of wills and operations is essentially attributed to his natures. For he himself was able to will and to act according to both of his natures, as it has been said, for our salvation" ${ }^{\prime \prime}$.

If Pyrrhus makes the will composite ( $\sigma v v \theta \varepsilon \tau o ́ s)$, the new will would be a sort of tertium quid, neither like a human will nor like a divine will, alienating the Son not only from man but from the Father as well, in addition to causing in Christ an anti-Chalcedonian mixture ${ }^{40}$.

volonté contraire: si la volonté humaine est niée c'est parce qu'il faut à tout prix nier la contrariété. Serge avait parfaitement réussi puisqu'il avait amené le pape à formuler explicitement le monothélisme: une seule volonté de Notre Seigneur Jésus Christ" (F.-M. Léthel, La prière de Jésus à Gethsémani dans le controverse monothélite, in: Actes du Symposium sur Maxime le Confesseur, Fribourg, 2-5 septembre 1980, ed. F. Heinzer - Ch. Schönborn, Paradosis 27, Fribourg 1982, 211.

${ }^{37}$ Maximus, of course, summons many additional Scriptural accounts to his defense against the monothelites (cf. Maximus Confessor, Disputatio cum Pyrrho, PG 91, 320D - 328A).

${ }^{38}$ Idem, Opuscula theologica et polemica 6, PG 91, 68C, transl. Blowers -Wilken, in: On the Cosmic Mystery of Jesus Christ, p. 176.

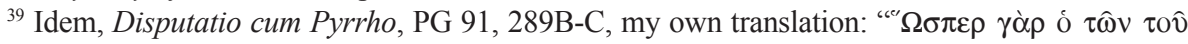

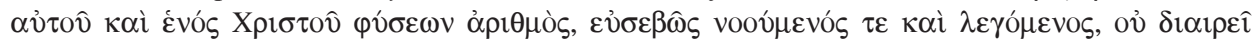

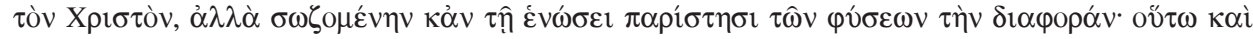

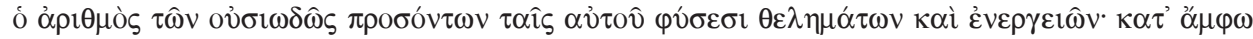

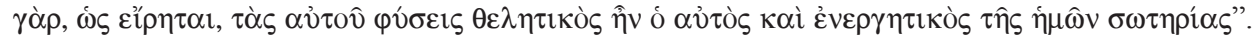

${ }^{40}$ Cf. ibidem, PG 91, 296C. 


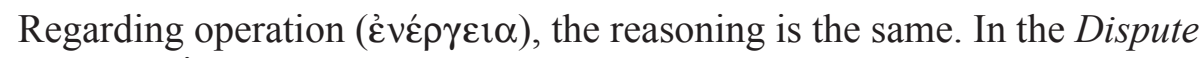
at Bizya, Maximus argues,

"The point is that, if you are to believe the holy Fathers, who say: «Those who have one activity have also one essence», you are making a quaternity ( $\tau \varepsilon \tau \rho \alpha \dot{\delta} \delta \alpha$ ) of the holy Trinity, in that Christ's flesh becomes one being with the Word, and stands aside from the cognate identity which by nature he has with us and with the woman who bore him"41.

A tetrad, however, is not theologically possible, of course. If Christ did truly assume human nature, then he assumed a human $\varepsilon$ हैं $\rho \gamma \varepsilon \imath \alpha$ as well. Maximus

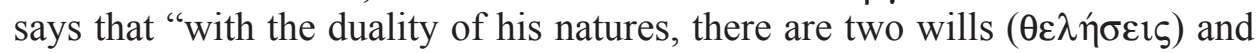

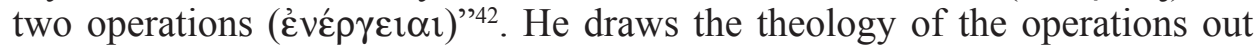
more fully in other places in his writings. In Ambgiuum 5, for instance, he says that we confess

"the two natures of Christ, of which He Himself is the hypostasis, and the natural energies of His two natures, of which $\mathrm{He}$ is the true union, since $\mathrm{He}$ performs the activities proper to each nature as a single subject, and in all His activities He reveals the energy of His own flesh, united inseparably to his divine power. For how will He be God by nature and man by nature without possessing completely what belongs to each nature in its natural constitution?"43.

Maximus extends this principle in this ambiguum by demonstrating that, for example, when Christ walks on the water it illustrates two operations at work - moving from place to place is a human operation, but the lightness upon the water shows the divinization of that very flesh of Christ ${ }^{44}$. One can see

${ }^{41}$ Idem, Disputatio Bizyae cum Theodosio 3, ed. and transl. Allen - Neil, p. 83. Cf. Basilius Caesariensis, Adversus Eunomium 4, 1.

${ }^{42}$ Maximus Confessor, Opuscula theologica et polemica 6, PG 91, 68A, transl. Blowers - Wilken, in: On the Cosmic Mystery of Jesus Christ, p. 174.

${ }^{43}$ Idem, Ambiguorum liber 5, PG 91, 1052C, transl. Constas, vol. 1, p. 43.

${ }^{44}$ Similar to Maximus, John of Damascus also points to the virginal birth and Christ's walking upon water as particularly effective Scriptural witnesses to the two operations: "Moreover, just as He received in His birth of a virgin superessential essence, so also He revealed His human energy in a superhuman way, walking with earthly feet on unstable water, not by turning the water into earth, but by causing it in the superabundant power of His divinity not to flow away nor yield beneath the weight of material feet. For not in a merely human way did He do human things: for He was not only man, but also God, and so even His sufferings brought life and salvation: nor yet did He energize as God, strictly after the manner of God, for He was not only God, but also man, and so it was by touch and word and such like that He worked miracles" (Johannes Damascenus, De fide orthodoxa 3, 15). John was likely drawing directly from Maximus. For both of them, this sequence can be traced to Dionysius the Areopagite. Cf. Dionysius Pseudo-Areopagita, Epistula 4 Caio Monacho, PG 3, 1072B, transl. C. Luibheid: Pseudo-Dionysius, Letter 4 to Gaius the monk, in: Pseudo-Dionysius: The Complete Works, Classics of Western Spirituality, New York 1987, 264: "Superior himself to the human condition he does the work of a man. A proof of this is that a virgin supernaturally bore him and that flowing water, bearing the weight of his corporal, earthly feet, did not yield, but, rather, 
that Maximus is interested in fully unpacking the ramifications of Chalcedon, according to Blowers and Wilken. This is further confirmed by the use throughout Maximus's works of the Chalcedonian adverbs mentioned above. In much the same way as we saw with Christ's wills, assigning operation only to the divinity and not to the humanity of Christ compromises redemption. To remove the human operation in Christ would be to negate his priesthood, and it is because of his priesthood that he is able to offer up a sacrifice for our salvation. The monenergist position ultimately leaves no role for humanity in redemption, so there is no priesthood, and no real cooperation between man and God in salvation. With respect to the consequences for our understanding the mystery of the Godhead, Maximus's thought strikes us again - denying natural will annuls the Creed itself. In his rebuttal to one of his accusers during his trial before his exile to Bizya, he recounted an earlier conversation the two had regarding the Typos document, which merely ordered silence concerning the number of wills and activities. Maximus understood silence to be, on the one hand, impossible for him, and on the other, a vehicle for subtly advancing heterodoxy, as it was for the Arians. When his interlocutor began to recite the Creed, Maximus interrupted to prove how he could not even get past "maker of heaven and earth" in the monothelite-monenergist paradigm because "God wouldn't be a maker were he deprived of a natural will and activity" ${ }^{45}$. Later in Bizya, regarding the imposed silence of the Typos, Maximus says,

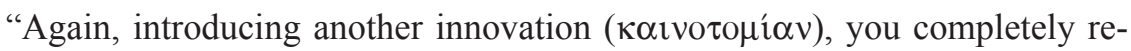
move everything which signifies and confirms the divinity and humanity of Christ, sanctioning by laws and decrees that neither one nor two wills or activities are to be spoken about in him, which is characteristic of something

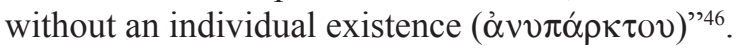

The Typos is not only anti-Incarnational, it dares to attempt to remove existence from the Son.

In sum, Maximus's struggle for orthodoxy regarding the wills and operations of Christ is not mere quibbling over insignificant distinctions, but has everything to do with theology and the economy of redemption itself. To err in

held him up with supernatural power". This is the very letter that became the basis for Maximus's Ambigua 5 cited above. Cf. also Dionysius Pseudo-Areopagita, De divinis nominibus 2, 9, PG 3, 648A, transl. Luibheid: Pseudo-Dionysius, Divine Names, in: Pseudo-Dionysius: The Complete Works, p. 65: "That he undertook to be a man is, for us, entirely mysterious. We have no way of understanding how, in a fashion at variance with nature, he was formed from a virgin's blood. We do not understand how with dry feet and with his body's solid weight he walked on the unstable surface of the water. And we do not understand whatever else has to do with the supernatural nature of Jesus".

${ }^{45}$ Relatio motionis factae inter dominum abbatem Maximum et socium eius atque principes in secretario 4, PG 90, 115D, transl. P. Allen - B. Neil, in: Maximus the Confessor and his Companions, p. 57.

${ }^{46}$ Idem, Disputatio Bizyae cum Theodosio 3, ed. and transl. Allen - Neil, p. 83-85. 
this matter would be to obliterate virtually all conciliar Trinitarian and Christological developments. As Maximus said in Opusculum 3,

"The purport therefore of Severus, and his followers, is by a certain natural diminishment to expel the assumed nature in the ineffable union, and to cover themselves with the defilement of Mani's fantasy, Apollinaris' confusion, and Eutyches' fusion. [...] Therefore there follows from the Severan premiss the collapse of theology, and there is introduced a kind of Arian polytheism, Sabellian atheism, and a pagan kind of Godhead that fights against itself' ${ }^{\prime 47}$.

On the surface, this may seem like raw hyperbole, but at this point in Maximus's life, having explored the full consequences of a collapse of natural will and operation, he knows what is at stake. It is clear for Maximus that Christ's hypostasis is composite ${ }^{48}$, but he does not have a composite nature. JeanClaude Larchet points out several reasons why a composite divine-human nature is impossible for Maximus. Since the parts of a composite nature would need to be co-temporal with each other, the divine uncreated nature could not be mingled with a created nature. Secondly, lacking a natural complementarity or common measure, such a union would be incongruous. Thirdly, since all composite natures do not proceed from free choice, it is all the more unfitting to ascribe a necessity of this union ${ }^{49}$. Indeed, to consider Christ as having a composite nature, Maximus says, would be to estrange him from the godhead and to forfeit the very union which he assumed ${ }^{50}$. He would neither truly be man nor would he truly be God, but he would be something altogether different. In fact, monothelitism and monenergism each destroy communion with God. Maximus says,

${ }^{47}$ Idem, Opuscula theologica et polemica 3, PG 91, 49C, transl. Louth, p. 195-196. This opusculum was originally thought by Sherwood to be one of the latest works of Maximus, though Jankowiak and Booth date this between 636 and 642 (cf. The Oxford Handbook of Maximus the Confessor, p. 61).

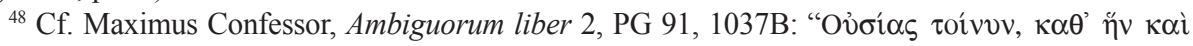

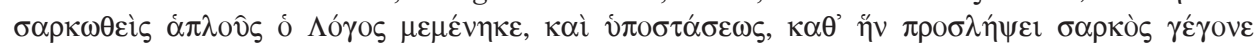

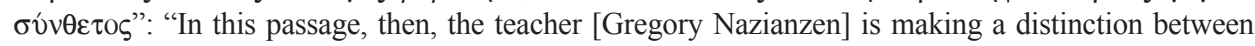
«essence», according to which the Word remained simple, even though He became flesh, and «hypostasis», according to which He became composite by the assumption of the flesh".

${ }^{49}$ Cf. Larchet, Introduction, p. 20-21: "Mais on ne peut attribuer, comme le font les sévériens, une nature composée au Christ. En premier lieu, Ses deux natures ne sont pas créées simultanément, puisque Sa divinité, incréée, préexiste à l'Incarnation de toute éternité. En deuxième lieu, elles ne s'impliquent pas ou ne se complètent pas naturellement l'une l'autre, puisque le surnaturel n'a aucune commune mesure avec le naturel. En troisième lieu, l'union de la nature divine et de la nature humaine dans l'hypostase du Verbe est le fruit non d'une nécessité physique, mais d'un choix délibéré: ce n'est pas par la loi de nature des composés, mais en outrepassant la nature des composés que le Verbe de Dieu S'est composé avec la chair, ineffablement, par assomption; c'est par Sa libre volonté, Son conseil et Son amour des hommes qu'Il S'est fait homme; c'est par mode d'économie, et non par loi de nature qu'Il est «devenu composé et incarné de nous»".

${ }^{50} \mathrm{Cf}$. Maximus Confessor, Epistula 12. 
"For either, as making a whole out of parts, we melt down the two essential wills and the same number of natural energies and recast them by composition as one will and one energy, as in the myths, and there is manifest something completely strange and foreign to communion with either the Father or with us, for he does not have by nature a composite will or energy, nor do we" ${ }^{\prime 51}$.

Under such a dispensation, the disciples of Christ then would not be Christians, but polytheists; consequently, sin would remain in humanity.

3. Continued relevance of Maximus. It would be fitting to consider briefly some impressions the confessor has left upon theology following his exemplary life. Most noteworthy is that Maximus through his own final ascetic struggle set the course for the triumph of dyothelite orthodoxy over the imperial interference in Constantinople ${ }^{52}$. This is an especially fitting historical note, as he consistently refuted his opponents through sound and subtle reasoning; imperial pressure, however, consistently reclaimed those same ecclesiastical leaders, as Emperor Constans was then the de facto ruler over the see of Constantinople. Thus, the most immediate effect of Maximus's efforts manifested itself at the sixth ecumenical council, following the reign of the monothelite Emperor Constans who had put both Maximus and Pope Martin to death. Constantinople

\footnotetext{
${ }^{51}$ Idem, Opuscula theologica et polemica 7, PG 91, 75A, transl. Louth, p. 183.

${ }^{52}$ It must be observed that others would suggest Maximus himself was the one interfering with imperial efforts at ecumenism. For example, Phil Booth in his imaginative but iconoclastic monograph, Crisis of Empire: Doctrine and Dissent at the End of Late Antiquity, Berkeley 2014, depicts Sophronius and Maximus as "intransigent" (ibidem, p. 259) and "subversive" (ibidem, p. 228) dissidents for their opposition to imperial attempts at a unified Christendom. Booth paints the Emperor Heraclius (and to a lesser extent Constans after him) as a great unifier who seems to have underestimated the recalcitrance of his monastic antagonists and is sympathetic to the idea that Sophronius and Maximus were dangerous dissidents perhaps guilty of political sedition (ibidem, p. 309). Booth's revisionist account fails on several fronts. First, while he describes Maximus as "belligerent" (ibidem, p. 315), he is too eager for his project to see Maximus as a political agitator. Thus, his account does not do justice to Maximus's irenic resistance recorded within the source material or for his openness to dialogue with his opponents. Nor does it account, secondly, for the barbaric display Emperor Constans made of those who would not assent to his compromise position. Finally, he describes the intellectual basis of Sophronius's opposition to imperial compromise as "not obvious or organic" (ibidem, p. 188). But if this is so, then why were Maximus's interlocutors convinced by his argumentation? Why did the sands of the empire's theological position shift so inconsistently with regard to will and operation? Booth, unfortunately, does not adequately account for the metaphysical, theological, and soteriological soundness of Sophronius's opposition to monenergism and Maximus's compelling opposition to both it and monothelitism. Booth seems unable to comprehend Maximus's resistance to compromise. What Booth imaginatively re-creates as Maximus's "provocation", that is, a political act of defiant insubordination, he fails to recognize as primarily the theological apologia of a humble and holy monk who risked life and limb to defend the confession of the faith against what he saw were dangerous innovations that threatened orthodoxy. In St. Maximus's view, the soundness of the dyothelite doctrine - as taught by the Fathers, especially Augustine - was something worth defending.
} 
III mentions four theologians, Athanasius, Gregory Nazianzen, Pope Leo, and Cyril of Alexandria, yet the omission of the name of Maximus is surprisingly glaring to us, considering the abundance of his dyothelite writings and the price Maximus paid ${ }^{53}$. There had to have been a reason for this, since his persona was known throughout the empire - North Africa, Italy, Asia Minor. Had his reputation been further smeared after his death? The existence of the seventh century Syriac vita ${ }^{54}$ demonstrates an active propaganda effort to smear the reputation of the confessor. I find, however, the Allen-Neil hypothesis convincing, namely, that he was not mentioned "probably to spare imperial embarrassment over his recent condemnation and martyrdom" ${ }^{55}$. Nonetheless, the dependence of the council on Maximus is clear. It is noteworthy that the council's treatment on the wills and operations ends in this manner:

"Thus, we glory in proclaiming two natural wills and actions concurring together for the salvation of the human race" 56 .

That bears a thematic resemblance to Maximus's teleology; compare, for example, with Opusculum 6:

"Let not what I will, but what you will prevail, inasmuch as, being God by nature, he also in his humanity has, as his human volition, the fulfillment of the will of the Father. That is why, considering both of the natures from which, and in which, and of which his person was, he is acknowledged as able both to will and to effect our salvation" ${ }^{\prime 57}$.

Because of his writings and for refusing a compromise, despite exile, imprisonment, and a series of trials, Maximus's tongue was cut out and his right hand was cut off. He and his companions (both named Anastasius) were sent into exile, Maximus to a fortress in Lazica ${ }^{58}$, one great monastic silence before he finally succumbed to his injuries that very year. It is quite a marvel that there was such a shift theologically as to allow the sixth ecumenical council to

${ }^{53}$ The council does, however, mention several familiar names in the anathemas, including Maximus's one-time dialogue partner Pyrrhus and even Pope Honorius, who seemed to have given support to the monothelite position, though apologetic defenses were given by his successors.

${ }^{54}$ Cf. An Early Syriac Life of Maximus the Confessor, transl. S. Brock, AnBol 91 (1973) fasc. 3, 299-346.

${ }_{55}^{55}$ Maximus the Confessor and his Companions, p. 30.

${ }^{56}$ Concilium Constantinopolitanum III (680-681), Definitio de duabus in Christo voluntatibus

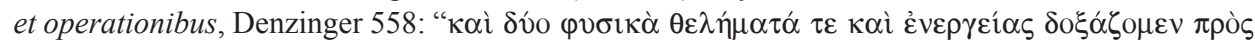

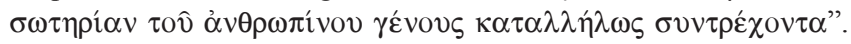

${ }^{57}$ Cf. Maximus Confessor, Opuscula theologica et polemica 6, PG 91, 67D, transl. Blowers - Wilken, in: On the Cosmic Mystery of Jesus Christ, p. 176.

${ }^{58}$ Cf. G.C. Berthold, Maximus the Confessor: Selected Writings, Classics of Western Spirituality, New York 1985, 31. The fortress was located in modern-day Tsageri, Georgia, near the Caucasus Mountains. 
denounce monothelitism and monenergism there in Constantinople less than twenty years after Maximus's martyria.

In former times, Maximus's role in the development of doctrine had been greatly undervalued, especially in the West, and he is only coming to be appreciated among theologians of recent generations. Whatever the reason, the times are ripe to harvest the theological import of the great confessor. While Maximus fell victim to the historical movement of his own day, his writings and disputes marvelously transcend that historical setting. Maximus ought to take on increasing significance after the Enlightenment. For example, his grappling with the problem of attributing $\gamma \nu \omega \mu \eta$ to Christ should show us what a careful thinker he was, for if one were to attribute vacillation between contraries in Christ, that would sound much like the modern and Ockhamist understanding of will. If willing means choosing between contraries, it is perfected in arbitrariness. Louth has noticed this well:

"The idea that Christ did not deliberate seems very strange to us post-Enlightenment (and especially post-Kantian) westerners, since deliberating between options is what we are accustomed to think that free will is all about"59.

But this cannot be attributed to Christ, the confessor says to us even today. Christ has indeed assumed our full nature, but He does not need to be like us in every manner of our sinful condition, and he should not be ${ }^{60}$. He has a composite hypostasis that points to the perfection of willing: doing the will of God. Otherwise, one may be confused into thinking that a struggle between contraries is the sign of a perfected will. Furthermore, living in the Spirit of Christ we are called to be theandric cooperators with God. Advocates of some modern

${ }^{59}$ A. Louth, St. John Damascene: Tradition and Originality in Byzantine Theology, Oxford 2002, 168.

${ }^{60}$ Cf. Thomas Aquinatus, Summa Theologiae III q. 18 a. 6 ad 3, ed. C.E. O'Neill: St Thomas Aquinas, Summa Theologiae. Latin Text, English translation, Introduction, Notes, Appendices and Glossary, vol. 50: The One Mediator (3a. 16-26), Cambridge - New York 1965, 84: "Ad tertium dicendum, quod agonia non fuit in Christo quantum ad partem animae rationalem, secundum quod importat concertationem voluntatum ex diversitate rationum procedentem; puta cum aliquis, secundum quod ratio considerat unum, vult hoc, et secundum quod considerat aliud, vult contrarium; hoc enim contingit propter debilitatem rationis, quae non potest dijudicare, quid sit simpliciter melius: quod in Christo non fuit: quia per suam rationem judicabat simpliciter esse melius, quod per ejus passionem impleretur voluntas divina circa salutem generis humani; fuit tamen in Christo agonia quantum ad partem sensitivam, secundum quod importat timorem infortunii imminentis, ut dicit Damasc. in 3. lib. (Johannes Damascenus, De fide orthodoxa cap. 18. a med. et cap. 20. et 23)" ("The agony in Christ was not in the rational soul, inasmuch as it implies a struggle in the will arising from a diversity of reasons, as when anyone, on his reason considering one thing, wishes it, and on its considering another thing, wishes the contrary. For this springs from the weakness of the reason, which is unable to judge which is the best simply. Now this did not occur in Christ, since by His reason $\mathrm{He}$ judged it best that the Divine will regarding the salvation of the human race should be fulfilled by His passion. Nevertheless, there was an agony in Christ as regards the sensitive part, inasmuch as it implied a dread of coming trial, as Damascene says"). 
approaches would benefit from a careful reading of the confessor. Some who would say "our work is God's work" conflate the separate activities of God and man into one, such as those who view man as a political agent who as a (sometimes violent) revolutionary accomplishes the work of God in history. Others, at the opposite extreme, view God as the sole agent in the sanctification of man, going so far as to deny man's participation in this effort altogether. The confessor's theology addresses this error, too, since the human nature is fully at work in the composite hypostasis of Christ. Man will not attain to $\theta \varepsilon \hat{\omega} \sigma ı \varsigma$ by standing idly, waiting for God to do all the work, for, as Anatolios says,

"The work of salvation is both a divine and human work, and it consists not in the mere juxtaposition of divinity and humanity but in the active transformation and deification of the human by the divine and the active reception of this transformation and deification by the divine" ${ }^{91}$.

The most important reason, however, for discovering the work of the confessor is the discovery of Jesus Christ. The monothelitism-monenergism crisis - and it really was no coincidence that it was a composite crisis in itself - was the quest for Jesus in the seventh century. If theology moves from Nicaea to Chalcedon, but stops there, we risk becoming disciples of Heraclius and reasoning with Constans. Arriving upon the topics of $\theta \varepsilon \lambda \eta \mu \alpha$ and $\dot{\varepsilon} v \varepsilon \dot{\varepsilon} \rho \gamma \varepsilon 1 \alpha$ were an inevitable result of the natural progression begun from "Who do people say that I am?" The Church answered ecumenically and, as with rulings of other councils, Christians are always at risk of forgetfulness and the loss associated with an ecclesial memory lapse. Bringing these costly doctrines into the present century will bring with it fresh meaning to believers who want to know what it means to work with God and to do his will.

\section{(Summary)}

This paper examines Maximus the Confessor's thought concerning the pressing urgency of his day, namely, the threat posed by monothelitism and monenergism. What were the theological stakes, as he saw them, for orthodoxy that prompted such stark resistance to imperial attempts at a doctrinal compromise? The paper focuses first on the mode of union in the Incarnation and the manner of the assumption of the human nature, including a human will and a human operation. Maximus also manages to rescue orthodoxy's fathers, especially Gregory Nazianzen, Cyril of Alexandria, and Dionysius and from his opponents' interpretations of various $\dot{\alpha} \pi$ opíat. The second section considers Maximus's presentation of the synthetic heterodoxy and its inevitable result, namely that one composite will in Jesus Christ

${ }^{61} \mathrm{Kh}$. Anatolios, The Soteriological Grammar of Conciliar Christology, "The Thomist" 78 (2014) 177. Thunberg draws similar conclusions in: Man and the Cosmos: The Vision of St. Maximus the Confessor, Crestwood (NY) 1997, 51-65. Cf. B. Studer, Zur Soteriologie des Maximus Confessor", in: Actes du Symposium sur Maxime le Confesseur, p. 239-246. 
- in isolating Christ from the Godhead on the one hand and from true humanity on the other - ultimately destroys all of theology. How can Christ save or divinize man if he is no longer like man? He cannot, says Maximus. Instead, Christ would become a sort of tertium quid, neither God nor man, in one movement unraveling Trinitarian theology, Christology, and soteriology. The concluding section briefly considers the immediate impact of Maximus from his martyrdom, including the matter of Constantinople III's strange failure to mention Maximus in the conciliar text. Finally, this section explores Maximus in our own time, especially how the theology that developed in the seventh century through Maximus is a sort of answer to some of the difficulties of post-Enlightenment modernity.

\section{OBRONA SYSTEMU TEOLOGICZNEGO. \\ DIOTELETYZM MAKSYMA WYZNAWCY JAKO BASTION TEOLOGII TRYNITARNEJ, CHRYSTOLOGII I SOTERIOLOGII}

\section{(Streszczenie)}

Niniejszy artykuł analizuje myśl Maksyma Wyznawcy dotyczącą palącego problemu jego czasów, a mianowicie zagrożenia stwarzanego przez monoteletyzm i monenergizm. Jakie było teologiczne ryzyko dla ortodoksji, i jak on je postrzegał, skoro stawił tak mocny opór wobec cesarskich prób doktrynalnego kompromisu? Autor w pierwszej części artykułu omawia zagadnienie sposobu zjednoczenia we wcieleniu i przybrania natury ludzkiej, w tym ludzkiej woli i ludzkiego działania. Maksym Wyznawca potrafi bronić prawowierności Ojców, zwłaszcza Grzegorza z Nazjanzu, Cyryla Aleksandryjskiego i Dionizego, także w kontekście interpretacji różnych $\alpha$ đopí $\alpha$ przez swoich przeciwników. W drugiej części artykułu przeanalizowano ujęcie heterodoksji w ogólności przez Maksyma i jego końcowy wniosek, a mianowicie, że postrzeganie zjednoczenia natur w Jezusie Chrystusie - pozbawiając Go natury Boskiej z jednej strony oraz prawdziwej natury ludzkiej z drugiej - ostatecznie zniszczy wszystko w teologii. Chrystus nie może zbawiać lub przebóstwiać człowieka, skoro sam nie jest już jak człowiek. Zamiast tego, Chrystus stał się swego rodzaju tertium quid, ani samym Bogiem, ani samym człowiekiem, jednym ruchem rozwikłując teologię trynitarna, chrystologię i soteriologię. W sekcji końcowej autor pokrótce rozważa bezpośrednie skutki wynikłe z męczeństwa Maksyma, w tym kwestię dziwnego braku wzmianek o nim w tekstach Soboru Konstantynopoliatńskiego III. Wreszcie, autor odnosi się do Maksyma w kontekście naszych czasów, podejmując zwłaszcza następujące zagadnienie: jak jego teologia, powstała w VII wieku, może być swego rodzaju odpowiedzią na niektóre trudności post-oświeceniowej nowoczesności.

Key words: Council of Chalcedon, Council of Constantinople III, Cyril of Alexandria, Dionysius the Areopagite, Gregory Nazianzen, Maximus the Confessor, Pyrrhus of Constantinople, monenergism, monothelitism. 
Słowa kluczowe: Sobór Chalcedoński, Sobór Konstantynopolitański III, Cyryl z Aleksandrii, Dionizy Pseudo-Areopagita, Grzegorz z Nazjanzu, Maksym Wyznawca, Pyrrus z Konstantynopola, monoenergizm, monoteletyzm.

\section{BIBLIOGRAPHY}

\section{Sources}

An Early Syriac Life of Maximus the Confessor, transl. S. Brock, AnBol 91 (1973) fasc. 3, 299-346.

Basilius Caesariensis, Adversus Eunomium, ed. B. Sesboüé - G.M. du Durand - L. Doutreleau, vol. 1, SCh 299, Paris 1982, vol. 2, SCh 305, Paris 1983.

Concilium Constantinopolitanum III (680-681), Definitio de duabus in Christo voluntatibus et operationibus, Denzinger 553-559.

Dionysius Areopagita Pseudo-, Epistulae, PG 3, 1065-1124.

Dionysius Areopagita Pseudo-, De divinis nominibus, PG 3, 586-996.

Disputatio Bizyae cum Theodosio, ed. and transl. P. Allen - B. Neil: Dispute at Bizya with Theodosius, in: Maximus the Confessor and his Companions: Documents from Exile, Oxford 2004, 76-119.

Gregorius Nazianzenus, Epistulae, PG 37, 21-388.

Gregorius Nazianzenus, Orationes 27-31, ed. P. Gallay, SCh 250, Paris 1978.

JoAnnes Damascenus, De fide orthodoxa, PG 94, 789-1228.

Maximus Confessor, Ambiguorum liber, PG 91, 1031-1417, transl. N. Constas: Maximus Confessor, On Difficulties in the Church Fathers: The Ambigua, vol. 1-2, Dumbarton Oaks Medieval Library 28-29, Cambridge (Ma) 2014.

Maximus Confessor, Disputatio cum Pyrrho, PG 91, 287-353.

Maximus Confessor, Epistulae, PG 91, 362-650.

Maximus Confessor, Liber asceticus, PG 90, 911-958.

Maximus Confessor, Opuscula theologica et polemica, PG 91, 9-286.

Maximus Confessor, Quaestiones ad Thalassium, PG 90, 244-785.

Relatio motionis factae inter dominum abbatem Maximum et socium eius atque principes in secretario, PG 90, 109-129.

\section{Literature}

Anatolios Kh., The Soteriological Grammar of Conciliar Christology, "The Thomist" 78 (2014) 165-188.

Balthasar Urs H. von, Cosmic Liturgy: The Universe According to Maximus the Confessor, transl. B.E. Daley, San Francisco 2003.

Berthold G.C., Did Maximus the Confessor Know Augustine?, StPatr 17 (1982) fasc. 1, 14-17.

Berthold G.C., Dyothelite Language in Augustine's Christology, StPatr 70 (2013) 357-364.

Berthold G.C., Maximus the Confessor: Selected Writings, Classics of Western Spirituality, New York 1985.

Blowers P., Maximus the Confessor and John of Damascus on Gnomic Will ( $\gamma \nu \omega ́ \mu \eta)$ in Christ: Clarity and Ambiguity, "Union Seminary Quarterly Review" 63 (2012) 44-50.

Blowers P., The Dialectics and Therapeutics of Desire in Maximus the Confessor, VigCh 65 (2011) 425-451. 
Воотн P., Crisis of Empire: Doctrine and Dissent at the End of Late Antiquity, Berkeley 2014.

BörJesson J., Augustine on the Will, in: The Oxford Handbook of Maximus the Confessor, ed. P. Allen - B. Neil, Oxford 2015, 212-234.

BörJesson J., Maximus the Confessor's Knowledge of Augustine: An Exploration of Evidence Derived from the Acta of the Lateran Council of 649, StPatr 68 (2013) 325-336.

DAley B.E., Making a Human Will Divine: Augustine and Maximus on Christ and Human Salvation, in: Orthodox Readings of Augustine, ed. G.E. Demacopoulos - A. Papanikolaou, Crestwood (NY) 2008, 101-126.

Daley B.E., Maximus Confessor, Leontius of Byzantium, and the Late Aristotelian Metaphysics of the Person, in: Knowing the Purpose of Creation through the Resurrection: Proceedings of the Symposium on St. Maximus the Confessor, Oct. 18-21, 2012, Belgrade, ed. Bishop M. Vasiljević, Belgrade 2013, 55-70.

Daley B.E., Word, Soul, and Flesh: Origen and Augustine on the Person of Christ, AugSt 36 (2005) fasc. 2, 299-326.

Garrigues J.-M., L'Instrumentalité Rédemptrice du Libre Arbitre du Christ chez Maxime le Confesseur, "Revue Thomiste" 104 (2004) fasc. 4, 531-550.

Heidgerken B., The Christ and the Tempter: Christ's Temptation by the Devil in the Thought of St. Maximus the Confessor and St. Thomas Aquinas, Dayton 2015 (Ph.D. diss.).

Jankowiak M. - Boоth P., A New Date List of the Works of Maximus the Confessor, in: The Oxford Handbook of Maximus the Confessor, ed. P. Allen - B. Neil, Oxford 2015, 19-83.

Jankowiak M., The Invention of Dyotheletism, StPatr 63 (2013) 335-342.

Kantzer Komline H., "Ut in illo viveremus": Augustine on the Two Wills of Christ, StPatr 70 (2013) 347-355.

Kantzer Komline H., The Second Adam in Gethsemane: Augustine on the Human Will of Christ, REAug 58 (2012) fasc. 1, 41-56.

LARChET J.-C., Introduction, in: Sainte Maxime Le Confesseur, Opuscules théologiques et polémiques, trad. et notes par E. Ponsoye, Sagesses chrétiennes, Paris 1998, 7-108.

LÉTHel F.-M., La prière de Jésus à Gethsémani dans le controverse monothélite, in: Actes du Symposium sur Maxime le Confesseur, Fribourg, 2-5 septembre 1980, ed. F. Heinzer - Ch. Schönborn, Paradosis 27, Fribourg 1982, 207-214.

LÉTHel F.-M., Théologie de l'Agonie du Christ: La liberté humaine du Fils de Dieu et son importance sotériologique mises en lumière par Saint Maxime Confesseur, Théologie Historique 52, Paris 1979.

LÉvy A., Le Créé et L'Incréé: Maxime le Confesseur et Thomas D'Aquin: Aux Sources de la Querelle Palamienne, Paris 2006.

Louth A., Maximus the Confessor, London 1996.

Louth A., St. John Damascene: Tradition and Originality in Byzantine Theology, Oxford 2002.

Madden N., Composite Hypostasis in Maximus Confessor, StPatr 27 (1993) 175-196.

Maximus the Confessor and his Companions: Documents from Exile, ed. and transl. P. Allen - B. Neil, Oxford 2004.

McFarland I.A., "Willing Is Not Choosing”: Some Anthropological Implications of Dyothelite Christology, "International Journal of Systematic Theology" 9 (2007) fasc. 1, 3-23.

McFarland I.A., The Theology of the Will, in: The Oxford Handbook of Maximus the Confessor, ed. P. Allen - B. Neil, Oxford 2015, 516-532. 
On God and Christ, transl. L. Wickham, Crestwood (NY) 2002.

SHerwood P., Annotated Date-list of Maximus'Works, Studia Anselmiana 30, Roma 1952.

Sherwood P., St. Maximus the Confessor: the Ascetic Life, the Four Centuries on Charity, Ancient Christian Writers 21, New York 1955.

Studer B., Zur Soteriologie des Maximus Confessor, in: Actes du Symposium sur Maxime le Confesseur, Fribourg, 2-5 septembre 1980, ed. F. Heinzer - Ch. Schönborn, Paradosis 27, Fribourg 1982, 239-246.

Thunberg L., Man and the Cosmos: The Vision of St. Maximus the Confessor, Crestwood (NY) 1997.

Thunberg L., Microcosm and Mediator: The Theological Anthropology of Maximus the Confessor, Lund 1965. 